\title{
Impact of promoting self-care in nursing workload*
}

\author{
Impacto da promoção do autocuidado na carga de trabalho de enfermagem \\ Impacto de la promoción del autocuidado en la carga laboral de enfermería
}

\author{
Armando dos Santos Trettene ${ }^{1,2}$, Cassiana Mendes Bertoncelo Fontes ${ }^{3}$, Ana Paula Ribeiro Razera ${ }^{4}$, Marcia Ribeiro \\ Gomide $^{1}$
}

\author{
How to cite this article: \\ Trettene AS, Fontes CMB, Razera APR, Gomide MR. Impact of promoting self-care in nursing workload. Rev Esc Enferm USP. 2016;50(4):633-639. DOI: http://
} dx.doi.org/10.1590/S0080-623420160000500014

\begin{abstract}
* Extracted from the thesis "Impacto da promoção do autocuidado na carga de trabalho de enfermagem", Hospital de Reabilitação de Anomalias Craniofaciais, Universidade de São Paulo, 2015.

${ }^{1}$ Universidade de São Paulo, Hospital de Reabilitação de Anomalias Craniofaciais, Bauru, SP, Brazil.

${ }^{2}$ Universidade Paulista, Campus Bauru, Bauru, SP, Brazil.

${ }^{3}$ Universidade Estadual Paulista "Júlio de Mesquita Filho", Faculdade de Medicina, Departamento de Enfermagem, Botucatu, SP, Brazil.

${ }^{4}$ Universidade de São Paulo, Hospital de Reabilitação de Anomalias Craniofaciais, Programa de Pós-Graduação em Ciências da Reabilitação, Bauru, SP, Brazil.
\end{abstract}

\begin{abstract}
Objective: To assess the impact of promoting self-care in nursing workload and associate it to the variables: age, gender, socioeconomic status, education, marital status and number of children of caregivers. Methods: Prospective study with 31 children and their caregivers. Participants were assessed at two moments, $1^{\text {st }}$ and $2^{\text {nd }}$ hospitalization, the nursing workload was measured by the Nursing Activities Score (NAS). Results: The mean NAS in the $1^{\text {st }}$ hospitalization was $60.9 \%$ and in the $2^{\text {nd }}$ hospitalization was $41.6 \%$, that is, 14.6 and 9.9 hours of nursing, respectively. The nursing workload on the first day of hospitalization was higher compared to the last day, both for the $1^{\text {st }}(p<0.001)$ and for the $2^{\text {nd }}$ hospitalization $(p<0.001)$, and higher in the first $(p<0.001)$ and in the last day $(\mathrm{p}=0.025)$ in the $1^{\text {st }}$ hospitalization. Comparing the $1^{\text {st }}$ hospitalization to the $2^{\text {nd }}$ hospitalization, the first was higher $(\mathrm{p}<0.001)$, and NAS items related to the training of self-care was influenced $(\mathrm{p}<0.001)$. Conclusion: The nursing workload associated to self-care promotion corresponded to 14.6 hours and was higher than determined by the existing legislation.
\end{abstract}

\section{DESCRIPTORS}

Nursing; Self-care; Workload; Personnel Downsizing; Subacute Care; Pierre Robin Syndrome.
Corresponding author:

Camila Daiane Silva

Rua Visconde de Paranaguá, 102, Centro

CEP 96203-900 - Rio Grande, RS, Brasil

camilad.silva@yahoo.com.br
Received: 03/05/2016

Approved: 05/24/2016 


\section{INTRODUCTION}

The assessment of nursing workload has been identified as an important management tool, since it is directly associated to the quality of care, patient safety, optimization of human resources and reduced costs, as it considers the complexity of care and the work process in a given population, contributing to the quantitative and qualitative aspects related to staff(1-2).

Historically, the staff number is directly related to hospital costs, constantly being targeted when it comes to cost containment. While an oversized staff entails high cost, a small staff can determine the reduction of the effectiveness or quality of care, prolonged hospital stay, increasing costs, increasing the incidence of risks to patients and professionals ${ }^{(2)}$.

Over time, the need to develop specific instruments to measure the nursing workload have been highlighted, especially in critical care units. The Therapeutic Intervention Scoring System (TISS) pioneered this approach ${ }^{(3)}$. However, with the development of physiological basis of severity indexes, TISS, after several versions, has been restructured and more targeted to assess care needs in the intensive care unit being called Nursing Activities Score (NAS) ${ }^{(3-4)}$.

NAS is composed by seven categories and 23 items $^{(3)}$. The availability of NAS, translated and validated for the Brazilian reality ${ }^{(4)}$, made possible its practical application in Brazil. Although originally designed for critical units, currently, its use is evident in different profiles of patients, demonstrating its effectiveness in different areas, including semi-intensive care units ${ }^{(5-10)}$.

Craniofacial deformities comprise a large and complex group covering isolated or multiple anomalies. Inside of this universe, the cleft lip and palate represents the most common non-syndromic malformations ${ }^{(11)}$.

The rehabilitation of patients with cleft lip and palate should be guided by an interdisciplinary care aimed at biopsychosocial and functional results. In this context, the nurse plays a relevant and essential role, mainly working as an educator in promoting self-care ${ }^{(12)}$.

Self-care is "the practice of activities that people play for their own benefit, to maintain life, well-being and health". Usually, adults take care of themselves; however babies, children and, in some situations, the elderly, require partial or total assistance, because they are at an early stage of physical, mental and psychosocial development. In such cases, they depend on a provider defined as self-care agent (SCA ${ }^{(13)}$.

Systems of education and guidance to health do not require sophisticated equipment or major procedures, leading some administrators to classify such assistance as minimum nursing care. However, they require professionals with great communication skills, availability, monitoring, evaluation, and welcoming posture, which undoubtedly requires time and professional competence, influencing the nursing workload ${ }^{(9,14)}$.

The Hospital de Reabilitação de Anomalias Craniofaciais of the Universidade de São Paulo is highlighted among the rehabilitation centers of patients with craniofacial anomalies and related syndromes. Particularly, in cases where anomalies are associated with syndromes, clinics or genetics, early hospitalization is necessary, which usually occurs in Semi-Intensive Care Units. In addition to assistance to children, SCA receive training for self-care, in order to maintain the care after hospital discharge.

Given the above, the question is: What is the impact of promoting self-care in nursing workload? A similar study was not found in the literature, showing the relevance of this research, an unprecedented approach. It is hoped that this publication will contribute to the adequacy of the nursing workload, considering its influence on quality of service, including patient safety, covering not only patients, families and caregivers, but the staff as a whole.

Thus, the objectives of this study were to assess the impact of promoting self-care in nursing workload and associate it to the variables: age, gender, socioeconomic status, education, marital status and number of children of caregivers.

\section{METHOD}

A prospective study conducted at the Hospital de Reabilitação de Anomalias Craniofaciais of the Universidade de São Paulo, in the Semi-Intensive Care Unit. This unit consists of eight beds, for the care of children between the ages of 1 day old to 2 years old with cleft lip and palate and associated syndromes. Nursing care is guided, among others, by the Theory of Self Care ${ }^{(13)}$.

The work is interdisciplinary and includes nurses, nursing technicians, physicians, physiotherapists, nutritionist, speech therapists and occupational therapists. The nursing staff consists of a nurse coordinator, four nursing assistants and eight nursing technicians who work in 6 hours/day and weekly working hours of 36 hours.

Children diagnosed with Robin Sequence account for 80\% of hospitalizations, characterized by a triad consisting of micrognathia, glossoptosis and posterior cleft palate in most cases. It can be presented alone (isolated Pierre Robin sequence) or in combination with clinical syndromes and other malformations ${ }^{(14)}$. They usually also develop respiratory and feeding difficulties. Among the treatment modalities we may include nasopharyngeal intubation, nasogastric tube feeding, and use of facilitative techniques of feeding ${ }^{(15-16)}$.

The sample consisted of 31 children who were hospitalized and their caregivers, between February and October 2014. The participation in the research had the inclusion criteria of caregivers, while for the children were: to remain hospitalized for longer than 24 hours and be accompanied by caregiver; to stay with nasopharyngeal intubation, nasogastric tube and/or techniques enabling feeding.

The research began after the approval of the Research Ethics Committee involving Human Beings at the Hospital, protocol number 512376 and CAAE: 25895513900005441. All participants formalized their participation by signing the Informed Consent form, according to the precepts of Resolution 466/12.

Children and their caregivers were assessed according to their nursing workload at two different moments, in the $1^{\text {st }}$ and $2^{\text {nd }}$ hospitalization. During the $1^{\text {st }}$ hospitalization, caregivers were trained by the nursing staff about the care related to children with isolated Robin Sequence, that is, during the $1^{\text {st }}$ hospitalization nursing promoted self-care. It is noteworthy that among the criteria for hospital discharge, we included caregiver training regarding the maintenance of home care. 
In the $2^{\text {nd }}$ hospitalization, the child was evaluated for clinical evolution. As for caregivers, although they were already qualified for the care required of nursing, considering the changes concerning the treatment of the child, for example, in relation to the transition of diet management from gastric route to oral use.

To evaluate the nursing workload, we used NAS retrospectively every 24 hours. It is noteworthy that for the present study, we designed and validated a tutorial on data collection, in accordance with what was recommended by its authors ${ }^{(3)}$.

For the application of NAS, we observed a list of information on the shift changes (handoff), in addition to the notes in the medical record. Data collection was performed by the researcher, with the help of two nurses who worked in the Semi-Intensive Care Unit, who also received training on the application of NAS and did not know the objectives of this study.

Initially, the nursing workload was evaluated in both hospitalizations $\left(1^{\text {st }}\right.$ and $\left.2^{\text {nd }}\right)$. Later, there was a comparison between them to identify significant differences, focusing on items corresponding to support and care for family members, for including interventions related to the training of caregivers in caring for children with isolated Robin Sequence.

Some factors are seen as real or potential influencers in the skills acquisition process for the self-care, being called basic conditioning factors ${ }^{(3)}$, and in this study, the following conditioning factors were included: age, gender, socioeconomic status, education, marital status, number of children and family kinship of the caregiver. It is very important to consider these aspects in the implementation of the nursing process, since they contribute to the identification of individual needs of caregivers, showing essential information regarding the nurse's work plan. These variables were associated with nursing workload in the $1^{\text {st }}$ and $2^{\text {nd }}$ hospitalization.

The characterization of the children included age and gender. These variables were also associated with nursing workload. Later, nursing hours according to NAS in both hospitalizations were compared between each other and according to COFEN resolution for patients in semi-intensive care ${ }^{(17)}$. For this, we considered that each point of the NAS is equal to 0.24 hours $^{(3)}$.

For statistical analysis, we used the Student t-test to assess the association between nursing workload and the variables: socioeconomic status and gender. For the variables: education, marital status and number of children, we used Analysis of Variance and to the variable age, Pearson Correlation. We accepted as statistically significant differences the values of $\mathrm{P} \leq 0.05$ (5\%).

\section{RESULTS}

The study included 31 children with isolated Robin Sequence and their caregivers. The mean age was $26(\mathrm{SD}=16.9)$ days, with range 6-64 days, most were female (68\%). Regarding the characterization of caregivers, most were mothers (97\%), whose mean age was 24.7 (SD=5.4) years, married (74\%), with only child (71\%) in low socioeconomic class (61\%), with high school education (40\%).

A total of 519 NAS assessments were generated, 320 related to the $1^{\text {st }}$ hospitalization and 199 related to the $2^{\text {nd }}$ hospitalization. The mean duration of the $1^{\text {st }}$ hospitalization was $10.3(\mathrm{SD}=5.7)$ days, while the $2^{\text {nd }}$ hospitalization was 6.4 $(\mathrm{SD}=3.4)$ days.

There was a significant difference comparing the nursing workload by NAS mean between the first and the last day, in the $1^{\text {st }}(\mathrm{p}<0.001)$ and $2^{\text {nd }}$ hospitalization $(\mathrm{p}<0.001)$ (Table 1$)$.

Table 1 - Mean comparison of NAS between the first and the last day of each hospitalization - Bauru, SP, Brazil, 2014.

\begin{tabular}{lccccc}
\hline Variables & Characteristics & Mean & $\begin{array}{c}\text { Standard } \\
\text { deviation }\end{array}$ & $\boldsymbol{P}$ \\
\hline \multirow{2}{*}{$\mathbf{1}^{\text {st }}$ hospitalization } & NAS 1 ${ }^{\text {st }}$ day & 111.4 & 12.6 & \\
& NAS last day & 37.2 & 11.1 & $<0.001^{*}$ \\
& Difference & 74.2 & 16.2 & \\
\hline \multirow{2}{*}{$\mathbf{2}^{\text {nd }}$ hospitalization } & NAS 1 ${ }^{\text {st }}$ day & 73.0 & 20.9 & \\
& NAS last day & 32.9 & 7.8 & $<0.001^{*}$ \\
& Difference & 40.1 & 20.5 & \\
\hline
\end{tabular}

Student $\mathrm{t}$ test. ${ }^{*}$ Statistical significance $(\mathrm{p} \leq 0.05)$.

When comparing the nursing workload between the first day of the $1^{\text {st }}$ and $2^{\text {nd }}$ hospitalization, there was significant difference $(p<0.001)$ (Table 2$)$. The same analysis was carried out considering the last day of the $1^{\text {st }}$ and $2^{\text {nd }}$ hospitalization, being statiscally significant $(\mathrm{p}<0.027)$.

Table 2 - Mean comparison of NAS between the first and last day of each hospitalization - Bauru, SP, Brazil, 2014.

\begin{tabular}{|c|c|c|c|c|}
\hline Variables & Characteristics & Mean & $\begin{array}{l}\text { Standard } \\
\text { deviation }\end{array}$ & $P$ \\
\hline \multirow{3}{*}{$1^{\text {st }}$ hospitalization } & $\begin{array}{l}\text { NAS } 1^{\text {st }} \text { day of } 1^{\text {st }} \\
\text { hospitalization }\end{array}$ & 111.4 & 12.6 & \multirow{3}{*}{$<0.001^{*}$} \\
\hline & $\begin{array}{c}\text { NAS } 1^{\text {st }} \text { day } \\
\text { of } 2^{\text {nd }} \\
\text { hospitalization }\end{array}$ & 73.0 & 20.9 & \\
\hline & Difference & 38.3 & 21.7 & \\
\hline \multirow{3}{*}{$2^{\text {nd }}$ hospitalization } & $\begin{array}{l}\text { NAS last day of } \\
1^{\text {st }} \text { hospitalization }\end{array}$ & 37.2 & 11.1 & \multirow{3}{*}{$0.027^{*}$} \\
\hline & $\begin{array}{l}\text { NAS last day } \\
\text { of } 2^{\text {nd }} \\
\text { hospitalization }\end{array}$ & 32.9 & 7.8 & \\
\hline & Difference & 4.2 & 10.2 & \\
\hline
\end{tabular}

Student $\mathrm{t}$ test. ${ }^{*}$ Statistical significance $(\mathrm{p} \leq 0.05)$.

When comparing the nursing workload between the $1^{\text {st }}$ and $2^{\text {nd }}$ hospitalization, there was a significant difference $(\mathrm{p}<0.001)$ (Table 3$)$.

Table 3 - Mean Comparison of the two NAS hospitalizations Bauru, SP, Brazil, 2014.

\begin{tabular}{lccc}
\hline Characteristics & Mean & $\begin{array}{c}\text { Standard } \\
\text { deviation }\end{array}$ & $\boldsymbol{P}$ \\
\hline NAS in the $1^{\text {st }}$ hospitalization & 60.9 & 12.8 & \\
NAS in the $2^{\text {nd }}$ hospitalization & 41.6 & 7.3 & $<0.001^{*}$ \\
Difference & 19.3 & 13.2 & \\
\hline
\end{tabular}

Student $t$ test. ${ }^{*}$ Statistical significance $(p \leq 0.05)$.

Considering the NAS items regarding activities related to the promotion of self-care ( $7 \mathrm{a}$ and $7 \mathrm{~b}-$ support and care for family members), we observed significant difference $(p<0.001)$ when comparing $1^{\text {st }}$ and $2^{\text {nd }}$ hospitalization. 
Table 4 - Mean comparison of NAS between the two hospitalizations and items related to training of caregivers - Bauru, SP, Brazil, 2014.

\begin{tabular}{|c|c|c|c|c|}
\hline Variables & Characteristics & $\begin{array}{c}\text { Mean } \\
(\%)\end{array}$ & $\begin{array}{c}\text { Standard } \\
\text { deviation } \\
(\%)\end{array}$ & $\boldsymbol{P}$ \\
\hline \multirow{3}{*}{$1^{\text {st }}$ hospitalization } & $\begin{array}{l}\text { Item } 7 \mathrm{a} \text { in the } 1^{\text {st }} \\
\text { hospitalization }\end{array}$ & 53.9 & 13.8 & \multirow{3}{*}{$<0.001 *$} \\
\hline & $\begin{array}{l}\text { Item } 7 \mathrm{a} \text { in the } 2^{\text {nd }} \\
\text { hospitalization }\end{array}$ & 79.5 & 18.2 & \\
\hline & Difference & -25.6 & 22.5 & \\
\hline \multirow{3}{*}{$2^{\text {st }}$ hospitalization } & $\begin{array}{l}\text { Item } 7 \mathrm{~b} \text { in the } 1^{\text {st }} \\
\text { hospitalization }\end{array}$ & 46.1 & 13.8 & \multirow{3}{*}{$<0.001 *$} \\
\hline & $\begin{array}{l}\text { Item } 7 \mathrm{~b} \text { in the } 2^{\text {nd }} \\
\text { hospitalization }\end{array}$ & 20.5 & 18.2 & \\
\hline & Difference & 25.6 & 22.5 & \\
\hline
\end{tabular}

Student $\mathrm{t}$ test. *Statistical significance $(\mathrm{p} \leq 0.05)$

We sought to associate the nursing workload to the variables: age and gender, in relation to children, however, there was no significant difference in both the $1^{\text {st }}$ hospitalization (gender, $\mathrm{p}=0.811$; age, $\mathrm{p}=0.992$ ) and the $2^{\text {nd }}$ hospitalization (gender, $\mathrm{p}=1.00$; age, $\mathrm{p}=0.650$ ).

Finally, we sought to associate the basic conditioning factors (sociodemographic characteristics) of the caregivers to the nursing workload of the $1^{\text {st }}$ and $2^{\text {nd }}$ hospitalization. No significant differences were observed (Table 5).

Table 5 - Association between the mean NAS of each hospitalization and the variables of caregivers: socioeconomic status, education, marital status and number of children - Bauru, SP, Brazil, 2014.

\begin{tabular}{|c|c|c|c|c|c|}
\hline Variables & Characteristics & $\mathbf{n}$ & $\%$ & $\begin{array}{c}P 1^{\text {st }} \\
\text { hospital- } \\
\text { ization }\end{array}$ & $\begin{array}{c}P 2^{\text {nd }} \\
\text { hospital- } \\
\text { ization }\end{array}$ \\
\hline \multirow{2}{*}{$\begin{array}{l}\text { Socioeconomic } \\
\text { status }\end{array}$} & Medium & 12 & 39 & $0.470^{*}$ & $0.502 *$ \\
\hline & Low & 19 & 61 & & \\
\hline \multirow{5}{*}{ Education } & $\begin{array}{c}\text { Higher } \\
\text { education }\end{array}$ & 10 & 32 & $0.588^{* *}$ & $0.419^{* *}$ \\
\hline & $\begin{array}{l}\text { Incomplete } \\
\text { higher } \\
\text { education }\end{array}$ & 2 & 6 & & \\
\hline & High school & 12 & 40 & & \\
\hline & $\begin{array}{l}\text { Incomplete } \\
\text { high school }\end{array}$ & 5 & 16 & & \\
\hline & $\begin{array}{c}\text { Elementary } \\
\text { school }\end{array}$ & 2 & 6 & & \\
\hline \multirow{3}{*}{ Marital status } & Married & 23 & 74 & & \\
\hline & Separated & 1 & 3 & $0.177^{* *}$ & $0.449^{* *}$ \\
\hline & Single & 7 & 23 & & \\
\hline \multirow{3}{*}{$\begin{array}{l}\text { Number of } \\
\text { children }\end{array}$} & 3 or 4 & 2 & 6 & & \\
\hline & 1 & 22 & 71 & $0.614^{* *}$ & $0.353^{* *}$ \\
\hline & 2 & 7 & 23 & & \\
\hline
\end{tabular}

*Student t test. ${ }^{* *}$ Analysis of Variance. Statistical significance $(\mathrm{p} \leq 0.05)$.

To obtain a result suitable for comparison between the nursing workload according to NAS and total nursing hours recommended by Resolution COFEN for patients in semi-intensive care, it was necessary to turn this score in hours $^{(3,17)}$. Considering that each point of NAS corresponds to 0.24 hours, and the mean measured in the $1^{\text {st }}$ and $2^{\text {nd }}$ hospitalization was $60.9 \%$ and $41.6 \%$, respectively, 14.6 nursing hours were spent in the $1^{\text {st }}$ hospitalization and 9.9 nursing hours were spent in the $2^{\text {nd }}$ hospitalization in 24 hour periods.

\section{DISCUSSION}

In this study, when we analyzed the characteristics of patients in relation to gender, most were women, corroborating the literature by stating that isolated cleft palate is prevalent in this gender ${ }^{(11)}$. One should also consider that the isolated Robin Sequence is characterized, among others, by the cleft palate in $90 \%$ of cases, which may explain this result ${ }^{(15)}$.

The mean age of participants was 26 days, reflecting the need for early infant's hospitalization with isolated Robin Sequence, considering the respiratory and feeding complications inherent to denote immediate treatment, to avoid complications, including death. Infants whose hospitalization was late, often have worsening symptomatology, including, in addition to respiratory failure, malnutrition associated with dysphagia ${ }^{(15-16)}$. Both age and gender of the children did not influence the nursing workload in accordance with the literature that points out the association with the complexity and care profile $(9,18-19)$.

Regarding the caregivers, it was observed that neither did the basic conditioning factors influence the acquisition of skills related to self-care, nor the nursing workload. The main feature of the caregiver appears in the provision and training related to the maintenance of well-being and quality of life ${ }^{(13)}$.

As for the age of care, most were young people. This finding was similar to other studies ${ }^{(12,20)}$. Young people often have greater willingness and ease for learning, a factor that contributes to the acquisition of skills related to self-care ${ }^{(20)}$.

Regarding education, most completed high school, which was similar to another study ${ }^{(12)}$. It is believed that the higher the education level the greater ease understanding the information, and consequently greater ease in acquiring knowledge related to training for self-care.

Regarding socioeconomic status, most participants were low; significant result, considering the limitations of the lower classes on the activities of self-care. Nurses should develop with the family, a planning care at home, identifying the need for community support to ensure continuity of care $^{(12)}$.

Most caregivers had only one child, in accordance with the literature ${ }^{(12,20)}$. The higher the number of children, the greater the difficulty in providing the care, especially in infants with isolated Robin Sequence, because they require more attention and frequent care.

Regarding marital status, most participants were married. The support and family involvement in educational activities related to self-care are seen as important success factors in relation to the rehabilitation process ${ }^{(12,20)}$.

Most caregivers consisted of mothers, corroborating the literature ${ }^{(11,19)}$. The maternal presence strengthens the mother-child bond, and contribute to better response to 
treatment, minimizing the stress imposed by hospitalization and promotion of the training process for self-care, preventing potential complications. Mothers become collaborators, joining efforts for a holistic and humanized care ${ }^{(9)}$. The hospitalization is seen as propitious time to the training of caregivers, whose doubts are to be identified and resolved ${ }^{(12,16)}$.

Regarding the nursing workload in the $1^{\text {st }}$ hospitalization, it was $60.9 \%$, while in the $2^{\text {nd }}$ hospitalization it was 41.6\%. Studies carried out in Semi-Intensive Care Unit showed a mean NAS of $49.5 \%{ }^{(8-9)}$.

Research carried out aiming at identify the nursing workload in different nurseries of a Neonatal Unit, listed according to the severity of patients at low risk, medium risk, high risk and isolation, related mean NAS to complex care ${ }^{(21)}$. Another research conducted in the Pediatric Intensive Care Unit with a similar goal showed a mean NAS higher than $56 \%{ }^{(22)}$. Both studies allowed us to infer that the higher the complexity of the patient, the greater the nursing workload.

In contrast, recent studies showed an inverse relationship between the severity of the patient and greater nursing workload, relating this finding to the evolution of the patients to death ${ }^{(23)}$ and use of sophisticated technological support in care $^{(24)}$.

Other studies carried out in different contexts, showed that mean NAS varied, emphasizing that the nursing workload is related to the work process, cultural aspects, professional profile, level of dependence of patients, complexity of diseases, availability of equipment and physical plant ${ }^{(5-10,25-26)}$.

When comparing the mean NAS in the first and last day of hospitalization in both hospitalizations, there was a significant regression of the nursing workload. Similar results were observed in other studies ${ }^{(15,25)}$. We associated it to the fact that patients on the first day of hospitalization require more care, because they are in unfavorable conditions. One should also consider that family members are unprepared for self-care and are emotionally fragile ${ }^{(11)}$.

When we associate the $1^{\text {st }}$ and $2^{\text {nd }}$ hospitalization to nursing workload, there was a significant regression. Studies in Semi-Intensive Care Unit pointed out the hospital discharge or transfer to less complex units as the main outcome, demonstrating benefit of restoring the clinical conditions of the patients ${ }^{(8-9)}$.

The mean duration of the $1^{\text {st }}$ hospitalization was 10.3 days, while the $2^{\text {nd }}$ was 6.4 days, that is, in addition to reducing the nursing workload, promotion of self-care helped reduce the hospitalization period. The increased hospitalization influence the nursing workload ${ }^{(24)}$. Therefore, minimizing it has been pointed out as an important indicator of quality of care, to be associated with increased morbidity and mortality, of the readmissions and the total costs, including the economic and social costs ${ }^{(27)}$.

Considering NAS items related to activities related to the promotion of self-care (support and care for family members), there was significant difference by joining the $1^{\text {st }}$ and $2^{\text {nd }}$ hospitalization, that is, the training of caregivers influenced the nursing workload significantly. It is important to emphasize the relevance of the NAS as the assistance to the family. Other studies support this statement ${ }^{(9,21)}$. Clients and family members should be inserted early in supportingeducational system, from admission, with a view to involving them in care, as well as to reaffirm and structure its provider function of home care ${ }^{(12-13,20)}$.

For the success of the support-education system, communication between the nursing staff and caregivers should be effective, involving accessible language, learning at bedside, supervision for learning acquisition and individualized care plan, to act according to the needs and expectations. Maintaining a dialogical relationship between professionals and caregivers that the success of the teaching-learning process is supported in the literature ${ }^{(28)}$.

Work processes whose purpose is the training and orientation in health, are often classified as simplistic by managers, however, it requires highly skilled and available staff $^{(14,29)}$, which certainly contributes to the increase in nursing workload. In this context, this study points to the need to review the staff dimensioning required for this service, considering the significant increase in nursing workload. It is evident, therefore, the need to identify in advance the care demands of users, not only to consider the recommendations by official agencies.

Family members want to be informed by nurses on the care provided, rules and routines of the Unit, equipment, among other things, and receive patient information from the medical staff. In the Semi-Intensive Care Unit target of this study, caregivers remained throughout the daytime, which favors the support and educational process. The literature suggests an association between high nursing workload and support and care for family members ${ }^{(9,30-31)}$.

The challenge of nursing staff regarding the training of caregivers is emphasized, considering the influence that the quality of care has on the rehabilitation process. This observation is reinforced when it comes to infants with isolated Robin Sequence. It is evident, therefore, the need not only to train caregivers, but to assess the quality of care provided by them ${ }^{(12)}$.

When comparing the nursing workload according to the NAS hours and COFEN Resolution ${ }^{(17)}$, it was observed that NAS amount of hours was higher the amount required. Different investigations pointed out to this discrepancy ${ }^{(9,18,21)}$. The staff dimensioning regarding the care profile to promote self-care will be available to readers in a future publication.

At the end, it is considered appropriate to point out some limitations of this study, including the specificity of the work process and the profile of patients treated, which makes it impossible to generalize the results. Still, the retrospective application of NAS can somehow have influenced the results, considering that the prospective assessment has been recommended. Finally, the lack of national and international studies on this approach limited the comparisons. However, this study has an unprecedented approach, demonstrating the need to reconsider the nursing workload to promote training for self-care.

\section{CONCLUSION}

The nursing workload on the promotion of self-care corresponded to 14.6 hours and was higher than the 
determined by the existing legislation. Thus, conducting multicenter studies that measure not only the nursing workload or the ideal personal quantitative according to the specificity of the work process, but also their relationship to the quantitative available and their influence on the quality indicators are encouraged. It is also required further research to assess the impact of promoting self-care on the nursing workload, whether performed by the patient or caregivers.

\section{RESUMO}

Objetivo: Verificar o impacto da promoção do autocuidado na carga de trabalho de enfermagem e associá-la às variáveis: idade, gênero, classificação socioeconômica, escolaridade, estado civil e número de filhos dos cuidadores. Método: Estudo prospectivo, onde participaram 31 crianças e seus respectivos cuidadores. Os participantes foram avaliados em dois momentos, $1^{\mathrm{a}}$ e $2^{\mathrm{a}}$ internação, quanto à carga de trabalho de enfermagem mensurada por meio do Nursing Activities Score (NAS). Resultados: A média NAS na 1a internação foi de 60,9\%, e na 2a internação foi de 41,6\%, ou seja, 14,6 e 9,9 horas de enfermagem, respectivamente. A carga de trabalho de enfermagem no primeiro dia de internação foi maior quando comparada ao último dia, tanto na $1^{\mathrm{a}}(\mathrm{p}<0,001)$ como na $2^{\mathrm{a}}$ internação $(\mathrm{p}<0,001)$, e maior no primeiro $(p<0,001)$ e último dia $(p=0,025)$ na $1^{a}$ internação. Ainda, na $1^{\text {a }}$ internação, foi maior quando comparada à $2^{\mathrm{a}}$ internação $(p<0,001)$, e os itens NAS referentes à capacitação do autocuidado a influenciaram $(\mathrm{p}<0,001)$. Conclusão: A carga de trabalho de enfermagem referente à promoção do autocuidado correspondeu a 14,6 horas e foi superior ao determinado pela legislação existente.

\section{DESCRITORES}

Enfermagem; Autocuidado; Carga de Trabalho; Downsizing Organizacional; Cuidados Semi-Intensivos; Síndrome de Pierre Robin.

\section{RESUMEN}

Objetivo: Verificar el impacto de la promoción del autocuidado en la carga laboral de enfermería y asociarla con las variables: edad, género, clasificación socioeconómica, escolaridad, estado civil y número de hijos de los cuidadores. Método: Estudio prospectivo, en el que participaron 31 niños y sus respectivos cuidadores. Los participantes fueron evaluados en dos momentos, $1^{\mathrm{a}}$ y $2^{\mathrm{a}}$ hospitalización, en cuanto a la carga laboral de enfermería medida por medio del Nursing Activities Score (NAS). Resultados: El promedio NAS en la $1^{\text {a }}$ hospitalización fue del $60,9 \%$ y, en la $2^{a}$, fue del 41,6\%, es decir, 14,6 y 9,9 horas de enfermería, respectivamente. La carga de trabajo de enfermería el primer día de hospitalización fue mayor cuando comparada con el último día, tanto en la $1^{\mathrm{a}}$ ( $\left.\mathrm{p}<; 0,001\right)$ como en la $2^{a}$ hospitalización $(p<; 0,001)$, y mayor el primero $(p<; 0,001)$ y último día $(p=0,025)$ en la $1^{\text {a }}$ hospitalización. En la $1^{\text {a }}$ hospitalización fue aún mayor cuando comparada con la $2^{\text {a }}$ hospitalización ( $\left.\mathrm{p}<; 0,001\right)$, y los ítems NAS referentes a la capacitación del autocuidado la influenciaron $(\mathrm{p}<; 0,001)$. Conclusión: La carga laboral de enfermería referente a la promoción del autocuidado correspondió a 14,6 horas y fue superior a lo determinado por la legislación existente.

\section{DESCRIPTORES}

Enfermería; Autocuidado; Carga de Trabajo; Reducción de Personal; Atención Subaguda; Síndrome de Pierre Robin.

\section{REFERENCES}

1. Lachance J, Douville F, Dallaire C, Padilha KG, Gallani MC. The use of the Nursing Activities Score in clinical settings: an integrative review. Rev Esc Enferm USP. 2015;49(n.spe):147-56.

2. Fugulin FM, Rossetti AC, Ricardo CM, Possari JF, Mello MC, Gaidzinski RR. Nursing care time in the Intensive Care Unit: evaluation of the parameters proposed in COFEN Resolution № 293/04. Rev Latino Am Enfermagem. 2012;20(2):325-32.

3. Miranda DR, Nap R, de Rijk A, Schaufeli W, lapichino G; TISS Working Group. Therapeutic Intervention Scoring System. Nursing activities score. Crit Care Med. 2003;31(2):374-82.

4. Queijo AF, Padilha KG. Nursing activities score (NAS): cross-cultural adaptation and validation to portuguese language. Rev Esc Enferm USP. 2009;43(n.spe):1018-25.

5. Panunto MR, Guirardello EB. Carga de trabalho de enfermagem em uma unidade de gastroenterologia. Rev Latino Am Enfermagem. 2009;17(6):1009-14.

6. Gouzou M, Karanikola M, Lemonidou C, Papathanassoglou E, Giannakopoulou M. Measuring professional satisfaction and nursing workload among nursing staff at a Greek Coronary Care Unit. Rev Esc Enferm USP. 2015;49(n.spe):15-21.

7. Silva JB, Póvoa VCO, Lima MHM, Oliveira HC, Padilha KG, Secoli SR. Nursing workload in hematopoietic stem cell transplantation: a cohort study. Rev Esc Enferm USP. 2015;49(n.spe):92-8.

8. Wolff LDG, Mazur CS, Wiezbick C, Barros CB, Quadros VAS. Dimensionamento de pessoal de enfermagem na unidade semi-intensiva de um hospital universitário de Curitiba. Cogitare Enferm. 2007;12(2):171-82.

9. Trettene AS, Luiz AG, Razera APR, Maximiano TO, Cintra FMRN, Monteiro LM. Nursing workload in specialized Semi-intensive Therapy Unit: work force size criteria. Rev Esc Enferm USP. 2015;49(6):958-63.

10. Reich R, Vieira DFVB, Lima LB, Rabelo-Silva ER. Nursing workload in a coronary unit according to the Nursing Activities Score. Rev Gaucha Enferm. 2015;36(3):28-35.

11. Freitas JAS, Neves LT, Almeida ALPF, Garib DG, Trindade-Suedam IK, Yaedú RYF, et al. Rehabilitative treatment of cleft lip and palate: experience of the Hospital for Rehabilitation of Craniofacial Anomalies/USP (HRAC/USP) - Part 1: overall aspects. J Appl Oral Sci. 2012;20(1):9-15.

12. Trettene AS, Razera AP, Maximiano TO, Luiz AG, Dalben GS, Gomide MR. Doubts of caregivers of children with cleft lip and palate on postoperative care after cheiloplasty and palatoplasty. Rev Esc Enferm USP. 2014;48(6):993-7. 
13. Orem DE. Nursing concepts of practice. 6th ed. St. Louis: Mosby; 2001.

14. Soares AV, Gaidzinski RR, Cirico MV. Nursing intervention identification in rooming-in. Rev Esc Enferm USP. 2010;44(2):307-16.

15. Salmen ICDM, Maques IL. In situ and home care nasopharyngeal intubation improves respiratory condition and prevents surgical procedures in early infancy of severe cases of Robin Sequence. Biomed Res Int. 2015;2015:1-7.

16. Trettene AS, Fiorotti L. Diagnósticos de enfermagem em lactentes com Sequência de Robin isolada. Nursing (São Paulo). 2011;14(163):641-4.

17. Conselho Federal de Enfermagem. Resolução COFEN nº 293, de 21 setembro 2004. Fixa e estabelece parâmetros para dimensionamento do quadro de profissionais de Enfermagem nas Unidades Assistenciais das Instituições de Saúde e assemelhados [Internet]. Brasília; 2004 [citado 2016 fev. 10]. Disponível em: http://www.cofen.gov.br/resoluo-cofen-2932004_4329.html

18. Brito AP, Guirardello EB. Carga de trabalho de enfermagem em uma unidade de internação. Rev Latino Am Enfermagem. 2011;19(5):1139-45.

19. Leite RL, Silva GRF, Padilha KG. Nursing Activities Score e demanda de trabalho de enfermagem em terapia intensiva. Acta Paul Enferm. 2012;25(6):837-43.

20. Trettene AS, Mondini CCDS, Marques IL. Feeding children in the immediate perioperative period after palatoplasty: a comparison between techniques using a cup and a spoon. Rev Esc Enferm USP. 2013;47(6):1298-304.

21. Nunes BK, Toma E. Dimensionamento de pessoal de enfermagem de uma unidade neonatal: utilização do Nursing Activities Score. Rev Latino Am Enfermagem. 2013;21(1):348-55.

22. Campagner AOM, Garcia PCR, Piva JP. Aplicação de escores para estimar carga de trabalho de enfermagem em unidade de terapia intensiva pediátrica. Rev Bras Ter Intensiva. 2014;26(1):36-43.

23. Beccaria LM, Contrin LM, Cesarino CB, Silva DC, Silva APA, Werneck AL. Association between nursing workload and the patient prognosis in Intense Care Unit. Bus Manage Rev. 2015;4(5):731-8.

24. Oliveira LB, Rodrigues ARB, Püschel VAA, Silva FA, Conceição SL, Béda LB, et al. Assessment of workload in the postoperative period of cardiac surgery according to the Nursing Activities Score. Rev Esc Enferm USP.2015;49(n.spe):79-85.

25. Peng L, Mayner L, Wang H. Association between trauma patients' severity and critical care nursing workload in China. Nurs Health Sci. 2014;16(4):528-33.

26. Padilha KG, Stafseth S, Solms D, Hoogendoom M, Monge FJC, Gomaa OH, et al. Nursing Activities Score: an updated guideline for its application in the Intensive Care Unit. Rev Esc Enferm USP. 2015;49(n.spe):131-7.

27. Giakoumidakis K, Baltopoulos GI, Charitos C, Patelarou E, Fotos NV, Brokalaki-Pananoudaki H. Risk factors for increased in-hospital mortality: a cohort study among cardiac surgery patients. Eur J Cardiovasc Nurs. 2012;11(1):23-33.

28. Gomes GC, Erdmann AL, Oliveira PK, Xavier DM, Santos SSC, Farias DHR. A família durante a internação hospitalar da criança: contribuições para a enfermagem. Rev Esc Anna Nery. 2014;18(2):234-40.

29. Nagata Y, Urakawa M, Kobayashi N, Kato S. Analysis on workload for hospital DOTS service. Kekkaku. 2014;89(4):495-502.

30. Stafseth SK, Solms D, Bredal IS. The characterization of workloads and nursing staff allocation in intensive care units: a descriptive study using the Nursing Activities Score for the first time in Norway. Intensive Crit Care Nurs. 2011;27(5):290-4.

31. Athanasiou A, Papathanassoglou ED, Patiraki E, McCarthy MS, Giannakopoulou M. Family visitation in greek intensive care units: nurses' perspective. Am J Crit Care. 2014;23(4):326-33. 